\title{
THE CONSTRAINING INFLUENCE OF THE CUSTODY-SECURITY EMPHASIS ON A COUNTY JAIL SCHOOL *
}

\author{
Lewis A. Mennerick \\ The University of Kansas
}

\begin{abstract}
This paper reports a case study of the educational program in a large, urban county jail. The operation of Metropolitan County Jail School is constrained greatly because the school is a low priority subsection of the much larger jail organization--an organization whose emphasis on custody-security conflicts with the school's manifest goal of education. The school is affected in various ways by three major custodially related processes: institutional routines, discipline, and institutional resources. Institutional security routines, for example, result in the almost daily delay of the start of school. The emphasis on discipline often results in the school being closed for one or more days when the inmates are being punished. And the lack of adequate institutional resources--specifically the quantity and quality of custodial personne 1--often results in security not being enforced. As a consequence, the school is affected as inmate students are affected emotionaliy by violent activities on the tiers. To the extent that the conflict between custody and rehabilitation is resolved, it is resolved through the teachers' acceptance of custody as the organization's primary goal. The teachers attempt to cope with the conflict through flexibility and compromise: through the exchange of favors and through "wheeling and dealing." Finally, in discussing the implications of the present study, I argue that the jail's custody-security emphasis can be explained largely by the constraints exerted on the larger jail organization by organizations and individuals in its external environment.
\end{abstract}

The conflict between custody-security and treatment in penal institutions al ready has received considerable attention from sociologists (Cressey, 1959; Galliher, 1972; Grosser, 1960; Grusky, 1959; Powelson and Bendix, 1951; McCleery, 1961; Messinger, 1969; Ohl in, 1960; Robinson, 1947; and Zald, 1960). In the present paper, however, we will shift the focus from penitentiaries, prison farms, and training schools to a lesser studied type of penal institution: the county jail. (For a review of literature on city and county jails, see Mennerick, 1971:4-26.) We will concentrate in particular on the relation between the custodial and school programs in a large, urban detention facility: Metropolitan County Jail. The jail school exists within a broader milieu of organizations, including the courts, the city and county in which the jail school is located, and the jail organization itself. And the school is greatly influenced, directly and indirectly, by these organizations in its external environment. (For discussions of the relation of an organization to its external environment, see, for example: Freidson, 1963; Gross, 1965; 
Mennerick, 1971:54-75; 01sen, 1968:21-29; and Zald, 1960:59-62.) Specifically, the school is constrained by virtue of being a subsection of the much larger jail organization--an organization which has custodial goals and priorities in conflict with the goals of the school. The jail school program, instituted to remedy educational problems, has been undermined by several processes related to the priority of custodial concerns.2 These processes include institutional routines, discipline, and institutional resources.

In the present paper, I first discuss the relative priority of custody versus treatment. I then discuss each of the previously noted processes as well as ways in which school personnel attempt to cope with problems resulting from the custody-security emphasis. The present paper represents, in part, a replication of previous studies dealing with the custody-treatment conflict in prisons and other types of penal institutions. More importantly, it focuses attention on the county jail as a unique, but too often ignored, type of penal organization. In the conclusion, I discuss implications of the present study and stress the need for increased sociological research in the jail as an important type of organization.

\section{Research Setting and Method}

Metropolitan County Jail, housing an average of approximately 1,800 inmates, is located in a large urban area. Like other jails, it provides temporary detention of individuals awaiting preliminary hearings or awaiting trial, and short-term incarceration of persons convicted of misdemeanor offenses. The jail school consists of two divisions, with facilities in the basement of two cell blocks. The academic section includes four classrooms, a principal's office, and an interviewing room, while the vocational section includes shops for shoe repair, wood working, and printing. The school staff consists of ten full-time teachers and a principal, supplied by the Metropolitan Board of Education. The school is open four hours a day, five days a week, 12 months a year. Normal daily enrollment is approximately 150 students. And while the jail takes adults of all ages, the school is restricted to male inmates, aged seventeen to twenty.

The present paper is based on data collected during sixty-seven days of participant observation in Metropolitan County Jail School: in the role of observer-researcher. I use excerpts from my field notes to illustrate and document the analysis. (For a detailed discussion of the methodology, see Mennerick, 1971:33-53.)

Cus tody Treatment:

The School's Lack of Priority

Security: high priority

The basic task of the Metropolitan County Jail is to confine prisoners, some convicted, some merely accused. Given the diversity of the prisoner population which includes some individuals charged with serious crimes, the jail operates as a maximum security institution. And while juvenile and adult, and sentenced and non-sentenced inmates are ordinarily housed on different tiers, little attempt is made to separate non-sentenced inmates according to the 
seriousness of their offense and according to the security threat they might pose for the jail. Rather, the organization is designed to be secure enough to hold individuals accused of the most serious crimes and imposes these security measures on virtually all inmates.

Manifestations of the security orientation are numerous but vary in substance and in degree of enforcement over time. They include electronic and manual frisking of visitors, "shakedowns" of inmates and their cells for items designated as contraband, censorshio of inmate mail, and the presence of steel bars, double-lock steel doors, guard towers, and security walls. However, in contrast to some other types of penal institutions, the task of maintaining security is made more difficult by the overcrowding and rapid turnover of inmates and by the inadequate number and quality of custodial personnel. Facilities designed to hold 1,302 inmates, now normally house around 1,800 inmates with an annual turnover of more than 20,000 inmates. Jail guards, hired on the bas is of political patronage, usually only receive "on the job" training. And the ratio of guards to inmates is several times below the accepted standard of one guard for every six or nine inmates.

Treatment: low priority

During our initial interview, the warden emphasized that educational programs in penal institutions are a white wash, especially when there is a rapid turnover of inmates. However, he also emphasized his interest in treatment by noting that he had recently proposed a new program which would provide for more efficient diagnostic classification of inmates and would include allocations for additional treatment personnel. He stressed that jail administrators and treatment personnel should work together.

However, the jail administrators' actual behavior, vis-a-vis the school, indicates that the school is not their primary concern. For example, the present study of the jail school initially was approved by the warden and by the sheriff without informing, much less consulting, the school staff. Similarly, at one point after I had begun field work in the jail, almost all sentenced school inmates were transferred from the county jail to the city jail. Even though the transfer of these inmates threatened the existence of the school's vocational training program, school personnel were not informed of the decision until they noticed that the boys were actualiy being transferred and then inquired. Another indicator of lack of priority is the jail administrators' failure to ensure that the guards bring the school inmates down to the school on time. Likewise, whenever school inmates are moved from one tier to another, school personnel must first determine where they have been moved to. Then they must inquire as to the proper security procedures for bringing the boys down to the school. While some of these are perhaps minor points, collectively they indicate the relative low priority of the school. If education-treatment were the administrators' first priority, school personnel would be consulted more often when their own interests are involved. However, this is not the case. Rather, other concerns--among them, maintaining a secure institution--take precedence; and it is up to the school to adapt to these concerns.

\section{Security as a Constraint}

The emphasis on custody-security affects the school through several processes: institutional routines, discipline, and institutional resources. 


\section{Institutional routines}

Although there are bars on the windows, the physical structure of the interior of the jail school resembles a school much more than it does a jail. Similarly, guards ordinarily are not present in the school area. Rather, it is the performance of custodial routines in the broader maximum security milieu in which the school exists --in the basement corridor and on the tiers in the jail--that constrains and disrupts the functioning of the school.

The custodial routine includes the frisking of inmate students upon leaving the school and shops. Likewise, the routine may prohibit or inhibit teachers from allowing their students to bring books or other study materials from the school to the tiers for studying at night. However, the most detrimental consequence of the security emphasis is the almost daily delay of school while the routine of "court calls" is being accomplished.

Each morning those inmates scheduled to appear in court that day are brought down from the tiers where they are housed to the basement corridor where their jail identification cards are checked to make certain that only authorized inmates will be taken to court. The inmates then undress and are searched to prevent contraband--including objects which could be used as weapons--from being taken from the jail to the court room. After re-dressing, the inmates are handcuffed and taken to the court building. While this movement--referred to as "court calls"--is in progress, only those guards and inmates directly engaged in the transfer are allowed in the corridor. And because inmate students must enter the main basement corridor in order to move from the tiers where they are housed to the school section, the guards do not bring them down tuntil after all calls have been completed. The reason is security; the consequence is the disruption of school activities as the start of the morning school session is delayed almost daily.

School administrator: Here come the doys--9:30.

Observer: What happens here in the morning? Does a guard go up and bring the inmates down around 9:30?

Administrator: Well, any time between nine-o'clock and ten. Not until the inmates, whose court date is up, have been moved. And that all depends. Nothing moves around here until these inmates have been moved through the corridor and over to the court building. . . . If there aren't too many [prisoners], and if the guards are all on time, and if they're not short of guards, then they may be through by $8: 45$ or nine-o'clock, but sometimes it's ten or later.

The school must accommodate the jail's demand for security: the jail's daily routine of inmate movement. The school cannot begin its normal activities until all court calls have been completed. Except for periodic inquiries and reminders to the guards, school personnel can do little but wait for the routine to be completed. Thus, the normal school day, which is already shortened to only four hours to allow time for the inmates' noon and evening meals, is frequently made even shorter due to the early morning movement of inmates to the courts. 
Discipline: maintaining order on the tiers

The school program is also affected as jail guards attempt to maintain order on the tiers housing school inmates. While the causes of trouble on the tiers vary, the result is often the same: disruption of normal school activities.

Non-sentenced jail school inmates normally are assigned to either the third or fourth tier of cell-block $A$, so as to facilitate their movement to and from the school, located in the basement of A-block. However, at one point, growing friction between Black inmates and white inmates resulted in the decision by jail administrators to segregate the two groups on different tiers for their own protection. The consequence for the school was explicit. The traditional full-day school session for all students was eliminated, as one tier of inmates attended school only in the morning, the other tier only in the afternoon. The school administrator described the situation as follows:

.. Some of the Negroes have been threatening the white boys. The whites are so outnumbered now that they don't have a chance. So they've taken all of the white boys off [tiers] three and four in A-block and put them all together with some older colored inmates on tier three. Now tier four is all colored. Don't get me wrong. This is not segregation--it's for their own protection--and it's not to say that the Negroes don't gang up on other Negroes, because they do. But there were so few white boys on each tier that they did't have a chance. White inmates even refused to come down to the school with the others--they were scared. Remember what I've said can easily happen on the stairs coming down here. . . A big burly boy can make a lot of trouble for another boy. . . And like I said, all kinds of things from fights to sexual abuses can go on in the cells without the guards finding out. So right now we 're bringing them down separately with one group coming down in the morning and the other down in the afternoon. We'd like to have them down all day, but it's something we' 11 have to work out.

Juvenile gang members from the larger community constitute another source of trouble on the tiers, especially when jail guards are unable to segregate members of gangs openly hostile to each other. Similarly, trouble may develop between cliques of inmates vying for control of the tier, or between two or more inmates, irrespective of gang or clique membership.

The guards often deal with trouble on the tiers in a collective manner. Unable to dtermine who is responsible, the guards punish all inmates on the tier. The tier is placed on "ban," meaning that the inmates are denied such privileges of using the television set, seeing the weekly movie on the tier, and purchasing cigarettes and extra food from the commissary. Usually, the school is also considered a privilege. Thus, when on ban, inmate students are not allowed to attend school. Jail guards--not teachers--decide whether or not the inmates may attend school. When the denial of school attendance is included as part of the punishment, the school ceases to function: sometimes for a day or two, sometimes for a week or longer. A teacher commented: 
Whenever they have trouble on the tiers, they usually end up putting the entire tier on ban--usually they can't find out exactly who caused the fight or whatever it might be. So they punish them all--take away their privileges. And they include the school in on this. After all, when the hoys come here, they can see their friends and talk. It's better than being up on the tier all day. Mr. Meyer [the principal] has been on them [custodial personne1] for a long time not to include the school. But it seems that they still always do it. They've [the inmates] been on the tier all week.

Again, the maintenance of security and order takes precedence over school activities.

Institutional resources: disorder on the tiers and delay of school

Although the manner in which custodial personnel deal with trouble on the tiers often has a debilitating effect on the school, jail officials do not become aware of all such problems. The overcrowding of inmates, the shortage of guards, and the physical structure of the tiers all impede the jail administration's ability to control activities on the tiers. Furthermore, some inmates have alleged that guards sometimes are aware of trouble and simply ignore it. Thus, a more subtle constraint is the imposition on individual inmate students of problems--such as fear for personal safety and concern for proper medical care--that students are not ordinarily expected to have to deal with.

Inmate student to school administrator: I want to go to the infirmary. Administrator: Is your name on sick-cail? Student: No. I've got veneral disease. And it's bothering me real bad this morning. I was down there [the infirmary] last night and they said they'd get me some pills. Administrator: Didn't they give you any penicillin? Student: No, they said I'm allergic to it--so they were going to send me some pills but I never got them. They've [the other inmates] been jumping me up on the tier. And it's real bad this morning. Can't I go to a doctor? Administrator: The doctor's not in yet. He won't be in until noon. Student: . . I don't want to go back up there [to the tier]. Administrator: Who's been jumping you? Can you name them? They [the guards] won't do anything for you unless you're willing to name names. Student: They've been jumping me. I don't know why. I didn't do anything to them. I shouldn't be in here. I didn't do anything. But they won't leave me alone. Last night they beat me up with what they called a "shit stick" and I'm not going up there again. [A shit stick is a large, heavy duty brush used for cleaning toilets.]

Thus, activities in the school's external environment have important consequences for the school. The school often is affected both when security is enforced and when it is not. When security is not enforced, when fights and other disorders are not controlled, students are affected emotionally. While we do not know the actual frequency of fights, extortion attempts, sexual assaults, and other disorders on the tiers, they do occur frequently enough so that the teachers take them into account when discussing problems of teaching in 
the jail school. As one teacher noted:

Most of the work here is remedial. . . . At the most you can keep their attention for half an hour or an hour. You may have a boy who's really enthusjastic one day and the next you can't reach him. Maybe he's had trouble--been in a fight.

Furthermore, the teachers realize that other non-violent incidents on the tier as well as the status of the inmate's case in court may also influence his behavior in school. In one case, for example, the teacher attributed a student's antagonistic behavior first to the outcome of the inmate's case in court and later to the fact that a jail guard had ordered the inmate to shave his beard. But most often, students are passive and apathetic. Teachers view their students as having many problems other than school to think about. And they expect less of them in the classroom.

... but you have to be a teacher, not a jailer. These boys need a break from the tiers--just like a man needs a break from his work. He needs to be able to come home--away from his work--and relax for a few hours. The school's the same for these guys. It gives them a chance to get away from everything that goes on up on the tiers--at least for a little while each day. The school's their isle of reprieve. You've got to be a teacher--not a jailer. They get enough with the guards. But that means you've got to walk the line. There's a lot of racial conflict around here... . There's a lot more conflict than you'd think.

Problems resulting from inadequate institutional resources are not limited to conflict on the tiers. As noted, for reasons of security, the start of school in the morning is often delayed while the guards complete the day's court calls. However, the start of school in the afternoon is also often delayed. The teachers attribute this delay, as well as some of the uncontrolled violence on the tiers, to the inefficiency and shortage of guards. More specifically, they see many of the guards, who are hired largely on the bas is of political patronage, as unqualified for, or disinterested in, their work. One school staff member described the situation as follows:

... If these guards don't have anything to do, then they just stand around there. It's the old political thing; just take it easy. . . . First there's the delay with moving the inmates who have to go to court. Then there are all these other little things that can arise from a lack of guards or pure laziness. . . . But the pay [for guards] is not that good and there's a lot of turnover.

Men who take the guard's job until a better job becomes available account for part of the turnover. However, due to the political patronage system, the greatest turnover--estimated to be close to eighty percent--occurs when a new sheriff from the opposing party is elected. In such cases, most incumbent guards are replaced by men who campaigned for the political party of the newly elected sheriff. Still other problems result from a shortage of guards. According to accepted standards, the county jail has been understaffed for many 
years. And when ten or fifteen guards do not report for work, jail operations are greatly impaired. The school and other low-priority sections of the jail are ignored as the limited manpower concentrates on the fundamental task of maintaining security. The shortage of guards as well as the lack of training for new guards contribute to the school's problems--including delays in the start of the school.

Observer: When these guards come in, do they give them any kind of training? School administrator: No. They're so short of help now. They just put a guy on a tier and tell another guard to show him what to do. So the inmates probably know more of the rules and regulations in the jail than some of the guards. [While we were talking, a teacher approached us. He was carrying a three by five inch notecard on the top of which he had printed the word "SCHOOL". Below that he had printed "A-3 A.M." and "A-4 P.M.".] Teacher to administrator: Is it okay if I give this [notecard] to the guards? They called up again this morning--they can never remember when to bring which group [of inmate students] down. Administrator: Yeah, I know--but I think we'd better wait on that.

Again the constraints of the external system--this time, institutional resources related to the patronage system and to the number and quality of guards-influence the operation of the school.

Teachers and Jailers:

The Resolution of Conflicting Goals

To the extent that the conflict between custody and rehabilitation in Metropolitan County Jail actually is resolved, it appears to be resolved through the teachers' acceptance of custody as the organization's primary goal. The teachers have learned through experience that the school is low priority. The teachers are employed by the Board of Education, not by the jail. They are, in effect, "guests" in the jail and in order to be allowed to remain they must make certain concessions. While school personnel do not like the almost daily delays and interruptions of school activities--and while they do express their displeasure to jail administrators from time to time--they have reconciled themselves to the futility of attempting to change the situation.

Relations between school personnel and jail administrators can be described in terms of flexibility and compromise: "give and take." Yet flexibility and compromise are largely characteristics of school personnel rather than jail administrators. The administrators compromise, but only to the extent that such actions will not be damaging to themselves and will not interfere with the basic emphasis on maintaining a secure institution. The school administrator commented:

... One thing you ought to know is that no one [jail personnel] around here likes to take the responsibility for anything. They've all learned the old army game: pass-the-buck. No one wants to make a decision. If you talk to one then they tell you to see the other. If you see the other they tell you to see the first one. Let me tell you, you really have to fight to get anything around 
here. . . When the jail was built, it just wasn't built for public service or for schools. And yet they keep increasing these things, but they don't increase the staff or the facilities. . . It's give and take. We get just about everything we request but we are very careful in what we do request. Make sure that we really need it.

Thus, jail school personnel must be persistent in their requests. Compromise and favors are also part of the strategy. However, favors sometimes cease to be favors and rather become part of the job. One example is the print shop. After the print shop was opened, the number of forms (such as the corridor passes, commissary "scripts," and various record-keeping forms) increased greatly. As the school administrator noted, "Now everyone who comes in here has a new form which he thinks he has to have." Another example is a vegetable garden which the school staff and some of the inmates started several years ago. Because the garden soil was in need of replenishment, school personnel arranged to have "black earth" brought in. However, jail personnel refused the request because of the threat to security that such activities would pose.

We1l aware that the formal channels of communication are often time-consuming and that the "buck" will likely be passed to some other official, school personnel use a variety of techniques to minimize the constraints implicit in the jail's emphasis on security. The school administrator, for example, often interacts with jail personnel in places other than their office: in the corridor, the lunch room, or in the commissary while taking a coffee break. Similarly, school personnel do favors because they know that they may have to ask favors from others. School staff members refer to this as "wheeling and dealing."

- . That's one thing around here. You don't get anything done unless you "wheel and deal." You do someone a favor because you know it might not be long before you'll need a favor for someone else. And by the time you go through all the channels, it'll be too late. You gotta go right to the top. The higher the better. . . That's the way you've got to do it to get anything done. Don't mess around with the sargeants. They're all afraid to do anything. They have to clear it wi th somebody else first. I always go right to the top. And if that doesn't work, I try the next level lower until I find someone who agrees. [He laughed.] I do it and I know Frank [the school administrator] does it.

Al though the potency of the teachers' bargaining position should not be overemphasized, school personnel do have several points of leverage in "wheeling and dealing" with jail staff. For example, to some extent, the school is a "showcase" for the jail administration. It is included on the itinerary whenever grand juries, civic groups, or other outsiders are allowed to tour the jail facilities. Second, the jail relies heavily on the vocational section of the school for the production of printed forms and other materials crucial to the functioning of the jait as a whole. Likewise, the shoe repair shop is as much a production unit as it is a teaching unit. A final point of leverage lies in the fact that the school itself contributes to the control of inmates. Unlike other sections of the jail where inmate-inmate and inmate-staff conflicts are 
common, school personnel are able to maintain relative order. One jail adminis trator commented:

.. So--but don't get me wrong. The school is also good for me. It means that for four hours a day I know where the boys are. I know that they're not up on the tiers getting into a fight or something so we can keep an eye on them.

\section{Conclusion}

The present study is relevant for those interested in correctional organizations because it focuses attention on the jail as an important and unique form of correctional organization. To date, sociologists have paid much attention to prisons while largely ignoring jails and other short-term detention facilities.

The present paper has focused on ways in which a county jail's concern for custody-security constrains and disrupts rehabilitation efforts. Pervious works dealing with the custody-treatment conflict have focused on prisons and other types of penal institutions and have offered differing findings. Powelson and Bendix (1951), for example, describe the conflicts between professional treatment personnel and custodial personnel which make standard psychiatric practices inapplicable. Similarly, Messinger (1969:237-286) notes various ways in which the emphasis on security--on controling inmates--affects the functioning of treatment programs at Deuel Vocational Institution. More generally, Zald $(1960: 60)$ notes that "since rehabilitation is a vague and difficult to establish criterion, a continuous pressure for emphasizing control instead of rehabilitation is implied, if an institution is to be free of demands for reorganization." In addition, Zald discusses the relation of the organization to the public and to both internal and external pressure groups and sugges ts that institutions are usually less autonomous when under departments of corrections. Grosser (1960) and $0 \mathrm{hl}$ in (1960) emphasize the importance of pressure from organized interest groups. Finally, building on Zald's (1960) work, Galliher (1972) concludes that the increasing emphas is on custody-security in the prison he studied--a prison that did not have a rehabilitation program--cannot be fully explained by inmate or staff pressure or by community pressures. Rather, he stresses the influence of decisions made by the Department of Correction.

Although the jail school data do not provide a straightforward explanation of what determines whether or not the external environment will influence rehabilitation programs, the data do suggest several factors that appear relevant. To explain the dominance of custody over treatment as resulting solely from the jail administration's ideological persuasions vis-a-vis custody-treatment overlooks some equally important organizational factors. I have stressed throughout this paper that the jail school is constrained by its environment, especially the jail. Yet the jail is also influenced, to varying degrees, by those organizations with which it interacts. Consider the following. First, the jail's basic task is to house prisoners, some of whom might be very dangerous if allowed to remain free. Second, the jail is a public, poljtical institution. Given the large number of patronage jobs involved, both the sheriff's position and the jail itself are important politically. And when a prisoner escapes or when something else goes wrong, local politicians and special interest groups as well as the local news media are quick to exert pressure on the jail administration. Third, while some people consider jails necessary and important, traditionally they have taken them for granted: except, of course, when the public is temporarily 
aroused by requests for larger appropriations, by prisoner escapes, or by reports of the scandalous conditions in many jails. Thus, while most people probably approve of education and rehabilitation, most are primarily concerned with keeping criminals in the jail and off the street. So when the question of security or rehabilitation arises, security usually prevails (cf. Zald, 1960:60). As the jail school administrator commented on one occasion, "All they [the jail administrators] have to do is throw the word security at us, and we're dead."

While the need for security may not necessarily preclude the possibility of a viable rehabilitation program, other conditions in Metropolitan County Jail make the task of security more difficult and thus indirectly result in attention being detracted from the rehabilitation program. Given the conditions of overcrowding of inmates, shortage of guards, questionable competence of some jail personnel, and physical structure of the jail, almost all resources must be concentrated on basic security. Thus, a variety of factors, including the jail's relation to the local political structure and the public's general support of security over treatment, combine to diminish the importance of the jail school. Certainly a much fuller understanding of the relative priority of security and treatment would be gained by detailed investigation of the ways in which organizations and individuals outside the jail constrain its activities so that a security-first policy is its only realistic option.

\section{Footnotes}

*This paper presents part of the findings of a larger study of a county jail school, supported by a National Institute of Mental Health grant, number R12 MH 9222. I thank Professor Howard S. Becker for his advice and encouragement in this research; I think Professor Kenneth C.W. Kammeyer for his comments on an earlier draft of this paper. For the complete study, see: "The Impact of the External Environment on a County Jail School," (unpublished Ph.D. dissertation, Northwestern University, 1971).

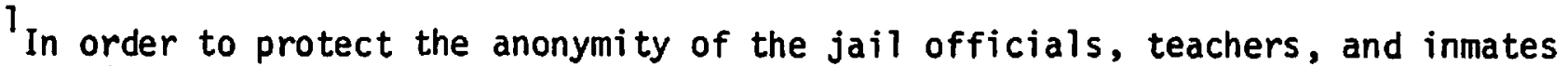
who allowed me to conduct the study upon which this paper is based, all names-including the name, Metropolitan County Jail--are pseudonymous.

2The jail school is also constrained because it lacks control over the kinds and number of students it gets. For a discussion of ways in which this constraint drastically affects enrollment and classification procedures, curriculum, and teaching techniques within the classrooms, see Mennerick, $1972: 75-84$. 


\section{References}

Cressey, Donald R.

1959 "Contradictory Directives in Complex Organizations: The Case of the Prison." Administrative Science Quarterly 4 (June):1-19.

Freidson, Eliot

1963 The Hospital in Modern Society. New York: The Free Press of Glencoe.

Galliher, John F.

1972 "Change in a Correctional Institution." Crime and Delinquency 18 (July):263-270.

Gross, Neal

1965 "The Sociology of Education," in Robert K. Merton, et. al. (eds.), Sociology Today. New York: Harper and Row, pp. 128-152.

Grosser, George H.

1960 "External Setting and Internal Relations of the Prison," Theoretical Studies in Social Organization of the Prison. New York: Social Science Research Council, Pamphlet \#15, pp. 130-145.

Grusky, Oscar

1959 "Role Conflict in Organization: A Study of Prison Camp Officials." Administrative Science Quarterly 3 (March):452-472.

McCleery, Richard H.

1961 "The Governmental Process and Informal Social Control," in Donald R. Cressey, ed., The Prison: Studies in Institutional Organization and Change. New York: Holt, Rinehart and Winston, pp. 149-188.

Mennerick, Lewis A.

1971 "The Impact of the External Environment on a County Jail School." Unpublished Ph.D. dissertation, Northwestern University.

Mennerick, Lewis A.

1972 "External Control of Recruits: The County Jail School." American Behavioral Scientist 16 (September-0ctober):75-84.

Messinger, Sheldon L.

1969 "Strategies of Control." Unpublished Ph.D. dissertation, University of California at Los Angeles.

Ohl in, Lloyd E.

1960 "Conflicting Interests in Correctional Objectives," in Theoretical Studies in Social Organization of the Prison. New York: Social Science Research Counci1, Pamphlet \#15, pp. 111-129.

Olsen, Marvin E.

1968 The Process of Social Organization. New York: Holt, Rinehart and Winston. 
Powelson, Harvey and Reinhard Bendix

1951 "Psychiatry in Prison." Psychiatry 14 (February):73-86.

Robinson, Louis $N$.

1947 "Contradictory Purposes in Prisons." Journal of Criminal Law and Criminology 37 (March-April):449-457.

Zald, Mayer N.

1960 "The Correctional Institution for Juvenile Offenders: An Analys is of Organizational 'Character'." Social Problems 8 (Summer):57-67. 